\title{
Integration Effect Between Biofertilizers and Natural Fertilizers on Growth, Npk Uptake and Yield Parameters of Wheat Plant Grown in Alkaline Soil
}

\author{
L. D. Shaaban ${ }^{(1)^{*}}$, K. E. Khalil, ${ }^{(2)}$, R. E. El-Tantawy, ${ }^{(2)}$. \\ ${ }^{I}$ Botany Department, Faculty of Science, Zagazig University, \\ 44519 and ${ }^{2}$ Plant Nutrition Department of Soils, Agricultural \\ Research center, Egypt.
}

\begin{abstract}
THE AIM of this study was to assess the effectiveness of mixed Bacillus strains applications. These strains are B. megaterium var phosphaticum which efficient in dissolving phosphate, $B$. circulans as potassium release bacteria and $B$. polymyxa as nitrogen fixer. The effect of the applied mixed bacillus strains, natural fertilizers and their interactions on the growth, nutrients uptake of nitrogen, phosphorus and potassium, and yield parameters of wheat plants grown in a potted soil under natural conditions were studies. The results revealed that, the application of biofertilizers (Bacillus strains) with natural fertilizers (rock phosphate and feldspar) in alkaline soil caused a significant increase in growth and macronutrients $(\mathrm{N}, \mathrm{P}$ and $\mathrm{K})$ at vegetative stage which directly enhanced the yield parameters of wheat plants. Moreover, these dual fertilizers caused significant increase in ions ( $\mathrm{N}, \mathrm{P}$ and $\mathrm{K}$ ) and crude protein contents of grains. It can be concluded that the combination between biofertilizers and natural fertilizers are one of the best modern tools and can replace the chemical fertilizers.
\end{abstract}

Keyword: Bacillus megaterium, B. circulans, B. polymyxa, Rock phosphate, Feldspar.

Wheat (Triticum aestivum L.) is considered as a strategic commodity crop in Egypt. It provides more than one, third of daily caloric intake of Egyptian consumers (Rosen, 1993). Wheat is the major stable crop produced in Egypt; its production doesn't meet the current demand. Wheat like other crops in Egypt suffers from the alkalinity of the soil which enhance the transformation of available $\mathrm{P}$ after short period of application to tricalcium phosphate which unavailable to plants (Zayed, 2005). Consequently, to achieve optimum crop yields, soluble phosphate excess fertilizer has applied at rates which caused unmanageable excess of phosphorus application (Brady, 1990). On the other hand, potassium deficiencies become problem because $\mathrm{K}$ decrease easily in soil due to crop uptake, run off, leaching and soil erosion (Sheng et al., 2002).

*Corresponding author: lamis shaaban@yahoo.com 
Direct rock phosphate (RP) and feldspar as potassium material (RK) are not readily available to plants because they are released slowly and their use as fertilizer often causes insignificant yield increases of current crops (Zapata and Roy, 2004). The conversion of insoluble phosphate in rocks into soluble forms available for plant growth is through acidification, chelation, and exchange reactions (Gerke, 1992). Nitrogen, phosphorus and potassium are known to be essential nutrients for plant growth and development. Intensive farming practices that achieves high yield require chemical fertilizers, which are not only costly but may also create environmental problems (Rigby and Caceres, 2001; Lee and Song, 2007).

The use of plant growth promoting rhizobacteria, including phosphorus and potassium solubilizing bacteria and nitrogen fixation bacteria, as biofertilizers, were suggested as sustainable solution to improve plant nutrient and production. The sound management of fertilization must attempt to ensure on both an enhanced and safeguarded environment, therefore, balanced fertilization strategy that combines the use of chemical, organic or biofertilizers must be developed and evaluated (Chen, 2006).

The aim of this study was to evaluate the potential of direct application of rock $\mathrm{P}$ and feldspar with mixed Bacillus strains efficient in dissolving phosphate, potassium release and nitrogen fixing for improvement of NPK uptake and their effects on vegetative growth and yield parameters of wheat plants grown in alkaline soil.

\section{Material and Methods}

Soil, used throughout the present study, was collected from the cultivated fields in Diarb Negm, Sharkia Governorate, Egypt. Chemical and physical properties of the collected soil samples were recorded in Table 1. Pot experiment was carried out at natural conditions at the botanical garden of the Faculty of Science, Zagazig University. The studied wheat grains (Triticum aestivum L.) cv. Sakha 93 was obtained from Agricultural Research Center, Giza, Egypt.

TABLE 1. Physical and chemical characteristic of experimental soil.

\begin{tabular}{|c|c|c|c|c|c|c|c|c|c|c|c|}
\hline \multicolumn{3}{|c|}{ Physical properties } & \multirow{2}{*}{$\begin{array}{c}\text { Organic } \\
\text { matter\% }\end{array}$} & \multirow{2}{*}{$\begin{array}{c}\text { E.C. } \\
\left(\mathbf{d s m}^{-1}\right)\end{array}$} & \multirow{2}{*}{$\mathbf{p H}$} & \multicolumn{5}{|c|}{$\begin{array}{c}\text { Total metal conc. } \\
(\mathbf{m g} / \mathbf{k g} \text { soil) }\end{array}$} \\
\cline { 1 - 7 } Clay & Silt & Sand & & & & $\mathbf{C a}^{+2}$ & $\mathbf{M g}^{+2}$ & $\mathbf{K}^{+}$ & $\mathbf{N a}^{+}$ & $\mathbf{C l}^{-}$ & $\mathbf{P}$ \\
\hline 51.67 & 20.65 & 27.1 & 10.4 & 1.96 & 8.1 & 9.13 & 3.4 & 1.2 & 8.2 & 6.2 & 6.26 \\
\hline
\end{tabular}

Bacillus strains; B. megaterium var. phosphaticum, B. circulans and $B$. polymyxa were kindly supplied from the Microbiology Department, Agriculture Research Center Giza, Egypt. Wheat grains were wetted by adhesive agent (5\% Arabic gum), then air dried for $30 \mathrm{~min}$. in shade after that inoculated by the solution of microorganisms using a liquid culture from Bacillus strains (B. megaterium, B. circulans and B. polymyxa) (Omar and Seddik, 2007).

Egypt. J. Bot., 55, No. 2 (2015) 


\section{Experiment}

Pot experiment using completely randomizing block design with three replications and nine treatments, (1) control without inoculation, (2) chemical fertilizers, super phosphate and potassium sulfate $(\mathrm{SP}+\mathrm{KS}),(3)$ rock phosphate (RP), (4) feldspar (RK), (5) rock phosphate + feldspar, (6) chemical fertilizers + Bacillus mixed strains, (7) rock phosphate + Bacillus mixed strains, (8) feldspar+ Bacillus mixed strains, (9) rock phosphate and feldspar + Bacillus mixed strains. Three grains of wheat were sown in each plastic pot, which was filled with $10 \mathrm{~kg} /$ pot of collected soil. Phosphorus was applied either as super phosphate $\left(15.5 \% \quad \mathrm{P}_{2} \mathrm{O}_{5}\right)$ at the rate of $0.15 \mathrm{~g} \mathrm{P} / \mathrm{kg}$ soil or fine rock - $\mathrm{P}$ $\left(22.5 \% \mathrm{P}_{2} \mathrm{O}_{5}\right)$ at a rate $0.10 \mathrm{~g} / \mathrm{kg}$ soil. Potassium was applied either as potassium sulfate $\left(48 \% \mathrm{~K}_{2} \mathrm{O}\right)$ with $0.05 \mathrm{~g} / \mathrm{kg}$ soil or rock-K (feldspar $11 \% \mathrm{~K}_{2} \mathrm{O}$ ) with a rate of $0.22 \mathrm{~g} / \mathrm{kg}$ soil. All treatments had received nitrogenous fertilizer (Ammonium nitrate $33.5 \%$ ) with a rate of $0.22 \mathrm{~g} / \mathrm{kg}$ soil and organic fertilizer (farmyard manure) at the rate of $0.67 \mathrm{~g} / \mathrm{kg}$ soil. The samples were collected for the mineral analysis at vegetative stage after 45 days from planting. The plants were harvested after 180 days from planting to determine the yield parameters and chemical analysis.

\section{Plant analysis}

Wheat plants were harvest and then separated into shoots and roots. Total dry weight of shoots and roots were determined after drying at $70{ }^{\circ} \mathrm{C}$ to a constant weight. The dried materials were digested by sulfuric acid for nitrogen determination by using the micro Kjeldahl method (Chapman and Pratt, 1961). Phosphorus was extracted by nitric acid and determined according to Frie et al., 1964. The potassium content was extracted and determined according to Allen et al. (1984). The method used for determination the nutrients ( N, P and $\mathrm{K}$ ) uptake was that of Chapman and Pratt (1961). Crude protein content of plant tissues was estimated according to Bishni and Hughers (1979).

\section{Statistical analysis}

The data obtained in the present study were subjected to analysis of variance according to Snedecor and Cochran (1982). Significant differences among treatment means judged with least significant difference (LSD) at 5\% level.

\section{Results and Discussion}

\section{Growth parameters}

Data showed that biofertilizers, natural fertilizers and/or chemical fertilizers and their interactions improved variability in the morphological parameters at vegetative stage (Table 2). The higher increase in the plant height $(40 \%)$ was recorded with combined application of biofertilizers and natural fertilizers (RP + RK) compared with control. Results also recorded significant increase in number of tillers $(70 \%)$, number of leaves $(73 \%)$, fresh weight $(73 \%)$ and total dry weight $(116 \%)$ per plant compared with control. These results are in accordance with previous studies of Yazdani et al. (2009) and Abd El-Ghany, et al. (2010). 
Similar values were obtained by the combination of biofertilizers with chemical fertilizers.

TABLE 2 . Effect of chemical and natural fertilizers (RP and or RK) with or without biofertilizers on growth parameters of wheat plants, after 45 days from planting.

\begin{tabular}{|c|c|c|c|c|c|}
\hline Treatment & $\begin{array}{c}\text { Plant } \\
\text { height } \\
(\mathbf{c m})\end{array}$ & $\begin{array}{c}\text { No of } \\
\text { Tillers/plant }\end{array}$ & $\begin{array}{c}\text { No of } \\
\text { leaves/plant }\end{array}$ & $\begin{array}{c}\text { F wt. of } \\
\text { shoot (g) }\end{array}$ & $\begin{array}{c}\text { D wt. of } \\
\text { shoot }(\mathbf{g})\end{array}$ \\
\hline Control & $42.00 \mathrm{~g}$ & $2.50 \mathrm{~d}$ & $9.50 \mathrm{e}$ & $1.67 \mathrm{e}$ & $0.48 \mathrm{f}$ \\
\hline $\mathrm{SP}+\mathrm{KS}$ & $51.00 \mathrm{e}$ & $3.00 \mathrm{~b} \mathrm{~d}$ & $13.00 \mathrm{~b} \mathrm{c}$ & $2.03 \mathrm{c} \mathrm{e}$ & $0.69 \mathrm{~cd}$ \\
\hline $\mathrm{RP}$ & $48.50 \mathrm{f}$ & $2.50 \mathrm{~d}$ & $11.50 \mathrm{~cd}$ & $1.91 \mathrm{de}$ & $0.68 \mathrm{~cd}$ \\
\hline RK & $48.50 \mathrm{f}$ & $2.75 \mathrm{~cd}$ & $12.00 \mathrm{~cd}$ & $1.82 \mathrm{de}$ & $0.55 \mathrm{e} \mathrm{f}$ \\
\hline RP+RK & $51.25 \mathrm{e}$ & $2.85 \mathrm{~cd}$ & $13.00 \mathrm{~b} \mathrm{c}$ & $2.12 \mathrm{c} \mathrm{e}$ & $0.71 \mathrm{~cd}$ \\
\hline$(\mathrm{SP}+\mathrm{KS})+\mathrm{bio}$. & $58.00 \mathrm{a}$ & $4.00 \mathrm{a}$ & $16.50 \mathrm{a}$ & $2.70 \mathrm{a}$ & $0.95 \mathrm{ab}$ \\
\hline $\mathrm{RP}+$ bio & $55.50 \mathrm{~b}$ & $3.25 \mathrm{~b} \mathrm{c}$ & $16.00 \mathrm{a}$ & $2.63 \mathrm{ab}$ & $0.88 \mathrm{~b}$ \\
\hline RK + bio & $54.50 \mathrm{~b} \mathrm{c}$ & $3.50 \mathrm{~b}$ & $14.00 \mathrm{~b}$ & $2.21 \mathrm{~b} \mathrm{~d}$ & $0.75 \mathrm{c}$ \\
\hline (RP+RK)+bio & $58.93 \mathrm{a}$ & $4.25 \mathrm{a}$ & $16.50 \mathrm{a}$ & $2.89 \mathrm{a}$ & $1.04 \mathrm{a}$ \\
\hline LSD & 2.25 & 0.47 & 1.04 & 0.40 & 0.09 \\
\hline
\end{tabular}

SP-super phosphate; KS-potassium sulfate; RP- rock phosphate; RK- feldspar.

Different letters within a column indicate a significant difference at $\mathrm{P} \leq 0.05, \mathrm{n}=3$.

These enhancements in growth parameters by the combined applications of biofertilizers (mixed strains) with natural fertilizers may be due to the ability of the bacillus to produce hormones, especially IAA (De Sousa and De Silva, 2012). The phosphate-dissolving bacteria (B.megaterium) also may have increased the uptake of phosphorus and trace elements (El-Haddad et al., 1993) which affect the nutritional status of plant and consequently enhance the growth. It is known that phosphorus and nitrogen play a major role in the molecular structure of nucleic acids DNA and RNA resulting in an increment of protein synthesis and protoplasm formation concomitantly with increases in vegetative growth (Mengel. and Kirkby, 1987 and El-Shanshoury, 1995).

Nitrogen, phosphorus and potassium uptake

Joints together biofertilizers and rocks $(\mathrm{RP}+\mathrm{RK})$ recorded highest values in the uptake of nitrogen (19.55), phosphorus (5.20) and potassium (50.65) $\mathrm{mg} /$ plant. In addition, nearby results obtained with the dual treatments (biofertilizers and chemical fertilizer) where the nitrogen, phosphorus and potassium uptake were 18.24, 4.47 and $45.6 \mathrm{mg} /$ plant respectively (Table 3). Han et al. (2006) demonstrated that the application of rocks (PR $+\mathrm{RK})$ with mixed strains of B. megaterium and B. circulans that solubilized them might provide faster and continuous supply of $\mathrm{P}$ and $\mathrm{K}$ for the plant. Therefore, it is possible that more available $\mathrm{P}$, due to solubilization by the bacteria, which may be caused also the enhancement of $\mathrm{N}$ uptake (Supanjani et al., 2006). It seemed that, the direct application of rock phosphate and rock potassium

Egypt. J. Bot., 55, No. 2 (2015) 
materials combined with biofertilizers may be agronomically more useful in alkaline soil and environmentally safe than chemical fertilizers (Rajan et al., 1996).

TABLE 3 . Effect of chemical and natural fertilizers, with or without biofertilizers on nitrogen, phosphorus and potassium uptake at vegetative stage (after 45 from planting).

\begin{tabular}{|c|c|c|c|}
\hline Treatment & $\begin{array}{c}\text { Nitrogen } \\
\text { (mg/plant) }\end{array}$ & $\begin{array}{c}\text { Phosphorus } \\
\text { (mg/plant) }\end{array}$ & $\begin{array}{c}\text { Potassium } \\
\text { (mg/plant) }\end{array}$ \\
\hline Control & $5.28 \mathrm{j}$ & $0.91 \mathrm{~h}$ & $14.98 \mathrm{~h}$ \\
\hline SP+ Ks & $10.35 \mathrm{e} \mathrm{g}$ & $2.07 \mathrm{e}$ & $27.95 \mathrm{e} \mathrm{f}$ \\
\hline PR & $8.91 \mathrm{f} \mathrm{h}$ & $2.04 \mathrm{e} \mathrm{f}$ & $25.09 \mathrm{f} \mathrm{g}$ \\
\hline KR & $7.08 \mathrm{i} \mathrm{j}$ & $1.49 \mathrm{f} \mathrm{g}$ & $21.4 \mathrm{~g}$ \\
\hline PR+KR & $10.72 \mathrm{e} \mathrm{f}$ & $2.13 \mathrm{e}$ & $29.039 \mathrm{~d} \mathrm{e}$ \\
\hline$(\mathrm{SP}+\mathrm{Ks})+\mathrm{bio}$ & $18.24 \mathrm{a}$ & $4.47 \mathrm{~b}$ & $45.6 \mathrm{~b}$ \\
\hline PR + bio & $15.4 \mathrm{~b}$ & $4.14 \mathrm{~b}$ & $38.19 \mathrm{c}$ \\
\hline KR + bio & $12.83 \mathrm{c} \mathrm{d}$ & $2.85 \mathrm{c} \mathrm{d}$ & $32.55 \mathrm{~d}$ \\
\hline$(\mathrm{PR}+\mathrm{KR})+\mathrm{bio}$ & $19.55 \mathrm{a}$ & $5.2 \mathrm{a}$ & $50.65 \mathrm{a}$ \\
\hline LSD 0.05 & 0.20 & 0.50 & 0.70 \\
\hline
\end{tabular}

SP-super phosphate; KS-potassium sulfate; RP- rock phosphate; RK- feldspar.

Different letters within a column indicate a significant difference at $\mathrm{P} \leq 0.05, \mathrm{n}=3$.

\begin{tabular}{|c|c|c|c|c|c|c|}
\hline Treatment & $\begin{array}{c}\text { No. of } \\
\text { Spike/ } \\
\text { plant }\end{array}$ & $\begin{array}{c}\text { No. of } \\
\text { grain / } \\
\text { plant }\end{array}$ & $\begin{array}{c}\text { Wt. of } \\
\mathbf{1 0 0 0} \\
\text { grains(g) }\end{array}$ & $\begin{array}{c}\text { Wt. of } \\
\text { grain/plant } \\
(\mathbf{g})\end{array}$ & $\begin{array}{c}\text { Straw } \\
\text { yield/plant } \\
(\mathbf{g})\end{array}$ & (G/S) \\
\hline Control & $1.50 \mathrm{e}$ & $34.50 \mathrm{~m}$ & $31.30 \mathrm{~g}$ & $1.08 \mathrm{j}$ & $0.92 \mathrm{~h}$ & 1.173 \\
\hline SP+ KS & $2.50 \mathrm{c}$ & $77.00 \mathrm{~g}$ & $37.27 \mathrm{e}$ & $2.87 \mathrm{e}$ & $1.56 \mathrm{~d}$ & 1.839 \\
\hline RP & $1.65 \mathrm{e}$ & $50.75 \mathrm{l}$ & $33.90 \mathrm{f}$ & $1.70 \mathrm{i}$ & $1.40 \mathrm{e} \mathrm{f}$ & 1.214 \\
\hline RK & $2.00 \mathrm{~d}$ & $59.00 \mathrm{i}$ & $33.90 \mathrm{f}$ & $2.00 \mathrm{f} \mathrm{g}$ & $1.23 \mathrm{~g}$ & 1.626 \\
\hline RP+RK & $2.50 \mathrm{c}$ & $75.50 \mathrm{~h}$ & $37.48 \mathrm{e}$ & $2.85 \mathrm{e}$ & $1.49 \mathrm{~d} \mathrm{e}$ & 1.899 \\
\hline$(\mathrm{SP}+\mathrm{KS})+\mathrm{bio}$. & $3.50 \mathrm{a}$ & $131.00 \mathrm{a}$ & $43.28 \mathrm{~b}$ & $5.67 \mathrm{a}$ & $2.30 \mathrm{a}$ & 2.465 \\
\hline RP + bio & $2.50 \mathrm{c}$ & $81.15 \mathrm{f}$ & $42.14 \mathrm{~b} \mathrm{c}$ & $3.42 \mathrm{~d}$ & $2.05 \mathrm{~b}$ & 1.668 \\
\hline RK + bio & $3.00 \mathrm{~b}$ & $100.0 \mathrm{c}$ & $43.00 \mathrm{~b}$ & $4.30 \mathrm{~b}$ & $1.82 \mathrm{c}$ & 2.362 \\
\hline$(\mathrm{RP}+\mathrm{RK})+\mathrm{bio}$ & $3.50 \mathrm{a}$ & $127 \mathrm{~b}$ & $45.04 \mathrm{a}$ & $5.72 \mathrm{a}$ & $2.33 \mathrm{a}$ & 2.454 \\
\hline LSD 0.05 & 0.23 & 1.35 & 1.35 & 0.17 & 0.12 & \\
\hline
\end{tabular}

SP-super phosphate; KS-potassium sulfate; RP- rock phosphate; RK- feldspar; G/S- ratio of grains : straw yield/ plant. Different letters within a column indicate a significant difference

at $\mathrm{P} \leq 0.05, \mathrm{n}=3$. 
The beneficial effect of Bacillus polymyxa may be attributed not only to its Nfixation ability, but also to its solubilization of organic phosphate compounds (Subba Rao, 1984), suppression of pathogenic organism in the rhizosphere (Holl et al., 1988) and caused an increase in aggregated soil particles by $57 \%$ which led to a more porous structure within the rhizosphere soil and consequently enhanced water retention and nutrient transfer in soil (Gouzou et al., 1993). Data also, showed that the combination of two rocks with biofertilizers was more effective than a single one, for enhancing the nutrient uptake by wheat plant. Such effect of biofertilizers on nutrients uptake may be due to its important role in changing soil $\mathrm{pH}$, where the solubilization of inorganic and organic phosphorus occur as consequence of the action of low molecular weight organic acids such as gluconic, succinic, lactic and citric acids which are synthesized by various soil bacteria (Rodriguez and Fraga 1999; Rodriguez et al., 2004). Also, it was concluded that the application of biofertilizers (triple Bacillus strains) combined with natural fertilizers $(\mathrm{RP}+\mathrm{RK})$ to alkaline soil increased the efficiency of $\mathrm{P}, \mathrm{N}$ and $\mathrm{K}$ minerals in soil. This increment in phosphorus uptake may be due to the decrease of soil $\mathrm{pH}$ and the increase of soil phosphatase activity.

\section{Chemical analysis of grains}

Table 4 showed clearly that, the NPK and protein contents in grain were significant higher with the application biofertilizers and natural fertilizers (PR $+K R)$ than the other treatments. The results are in agreement with those found by Mehrvarz and Chaich (2008), Kabesh et al. (2009) and Yasari et al. (2009). This could be attributed to the increase of ions absorption and translocation to spikes and the direct effect of bacteria on $\mathrm{P}$ and $\mathrm{K}$ availability in soil and nitrogen fixation (Premsekhar and Rajashree, 2009). In the present study, the results also recorded higher level of crude protein content in grains (49.3\%) with the application of biofertilizers and natural mineral fertilizers compared with the control. These results may be correlated to the increase of nitrogen and phosphorus absorption and translocation to plant which enhance the biosynthesis of protein.

TABLE 4 . Effect of chemical and natural fertilizers, with or without biofertilizers on ions (nitrogen, phosphorus and potassium) and protein contents of wheat grains.

\begin{tabular}{|c|c|c|c|c|}
\hline Treatment & Nitrogen \% & Phosphorus \% & Potassium \% & $\begin{array}{c}\text { Crud Protein } \\
\text { \% }\end{array}$ \\
\hline Control & $1.40 \mathrm{e}$ & $0.20 \mathrm{f}$ & $0.30 \mathrm{e}$ & $8.75 \mathrm{e}$ \\
\hline SP+ KS & $1.75 \mathrm{c} \mathrm{d}$ & $0.34 \mathrm{~d} \mathrm{e}$ & $0.38 \mathrm{~d}$ & $10.94 \mathrm{c} \mathrm{d}$ \\
\hline RP & $1.76 \mathrm{c} \mathrm{d}$ & $0.31 \mathrm{e}$ & $0.38 \mathrm{~d}$ & $11.00 \mathrm{c} \mathrm{d}$ \\
\hline RK & $1.74 \mathrm{c} \mathrm{d}$ & $0.24 \mathrm{f}$ & $0.39 \mathrm{c} \mathrm{d}$ & $10.88 \mathrm{c} \mathrm{d}$ \\
\hline RP+RK & $1.77 \mathrm{c} \mathrm{d}$ & $0.36 \mathrm{c} \mathrm{e}$ & $0.40 \mathrm{c} \mathrm{d}$ & $11.06 \mathrm{c} \mathrm{d}$ \\
\hline$(\mathrm{SP}+\mathrm{KS})+\mathrm{bio}$ & $2.02 \mathrm{a} \mathrm{b}$ & $0.45 \mathrm{a}$ & $0.50 \mathrm{a}$ & $12.63 \mathrm{a} \mathrm{b}$ \\
\hline RP + bio & $1.99 \mathrm{a} \mathrm{b}$ & $0.40 \mathrm{a} \mathrm{c}$ & $0.44 \mathrm{~b} \mathrm{c}$ & $12.44 \mathrm{a} \mathrm{b}$ \\
\hline RK+ bio & $1.87 \mathrm{~b} \mathrm{c}$ & $0.35 \mathrm{c} \mathrm{e}$ & $0.50 \mathrm{a}$ & $11.69 \mathrm{~b} \mathrm{c}$ \\
\hline$(\mathrm{RP}+\mathrm{RK})+\mathrm{bio}$ & $2.09 \mathrm{a}$ & $0.43 \mathrm{a} \mathrm{b}$ & $0.50 \mathrm{a}$ & $11.69 \mathrm{~b} \mathrm{c}$ \\
\hline LSD 0.05 & 0.18 & 0.05 & 0.05 & 1.13 \\
\hline
\end{tabular}

SP-super phosphate; KS-potassium sulfate; RP- rock phosphate; RK- feldspar.

Different letters within a column indicate a significant difference at $\mathrm{P} \leq 0.05, \mathrm{n}=3$.

Egypt. J. Bot., 55, No. 2 (2015) 


\section{Yield parameters}

In the present study the yield parameters were significantly increased with the combined application of biofertilizers and natural fertilizers, where the increase in number of spikes/ plant $133 \%$, number of grains/plant $69 \%$, weight of grains per plant $99 \%$, weight of 1000 grains $43 \%$ and finally the straw yield/plant $60 \%$, compared with control (Table 5). Other noteworthy, results showed that the combination between the biofertilizers and natural fertilizers (RP $+\mathrm{RK}$ ), increased the grain: straw ratio/plant $(\mathrm{G} / \mathrm{S})$ compared with control. This result suggested these dual fertilizers had positive effect on the production of wheat grains. Synergetic effects of biofertilizers and natural fertilizers have also been reported in various crops such as rice (Tiwari et al., 1989), sugar beet and barley (Cakamka et al., 1999) and hot pepper (Supanjani et al., 2006). These increments in yield parameters may be due to increase the solubilization of phosphate and potassium rocks, which increase the available $\mathrm{P}$ and $\mathrm{K}$ in soil, and hence stimulate growth and mineral uptake by plant (Park et al., 2003). Also, may be attributed to increase of nitrogen fixation by bacillus polymyxa which improve the vegetative growth and finally the yield of wheat plants (Premsekhar and Rajashree, 2009 \& Vessey, 2003). Data also showed that, the application of the two rocks fertilizers was more effective than a single one when combined with biofertilizers.

TABLE 5. Effect of chemical and natural fertilizers, with or without biofertilizers on wheat plant yield parameters.

\begin{tabular}{|c|c|c|c|c|c|c|}
\hline Treatment & $\begin{array}{c}\text { No. of } \\
\text { Spike/ } \\
\text { plant }\end{array}$ & $\begin{array}{l}\text { No. of } \\
\text { grain / } \\
\text { plant }\end{array}$ & $\begin{array}{l}\text { Wt. of } \\
1000 \\
\text { grains } \\
\text { (g) }\end{array}$ & $\begin{array}{c}\text { Wt. of } \\
\text { grain/pla } \\
\text { nt (g) }\end{array}$ & $\begin{array}{c}\text { Straw } \\
\text { yield/pla } \\
\text { nt (g) }\end{array}$ & $(\mathbf{G} / \mathbf{S})$ \\
\hline Control & $1.50 \mathrm{e}$ & $34.50 \mathrm{~m}$ & $31.30 \mathrm{~g}$ & $1.08 \mathrm{j}$ & $0.92 \mathrm{~h}$ & 1.173 \\
\hline $\mathrm{SP}+\mathrm{KS}$ & $2.50 \mathrm{c}$ & $77.00 \mathrm{~g}$ & $37.27 \mathrm{e}$ & $2.87 \mathrm{e}$ & $1.56 \mathrm{~d}$ & 1.839 \\
\hline $\mathrm{RP}$ & $1.65 \mathrm{e}$ & 50.751 & $33.90 \mathrm{f}$ & $1.70 \mathrm{i}$ & 1.40 e f & 1.214 \\
\hline RK & $2.00 \mathrm{~d}$ & $59.00 \mathrm{i}$ & $33.90 \mathrm{f}$ & $2.00 \mathrm{fg}$ & $1.23 \mathrm{~g}$ & 1.626 \\
\hline $\mathrm{RP}+\mathrm{RK}$ & $2.50 \mathrm{c}$ & $75.50 \mathrm{~h}$ & $37.48 \mathrm{e}$ & $2.85 \mathrm{e}$ & $1.49 \mathrm{~d} \mathrm{e}$ & 1.899 \\
\hline$(\mathrm{SP}+\mathrm{KS})+$ bio. & $3.50 \mathrm{a}$ & $131.00 \mathrm{a}$ & $43.28 \mathrm{~b}$ & $5.67 \mathrm{a}$ & $2.30 \mathrm{a}$ & 2.465 \\
\hline $\mathrm{RP}+$ bio & $2.50 \mathrm{c}$ & $81.15 \mathrm{f}$ & $42.14 \mathrm{~b} \mathrm{c}$ & $3.42 \mathrm{~d}$ & $2.05 \mathrm{~b}$ & 1.668 \\
\hline RK + bio & $3.00 \mathrm{~b}$ & $100.0 \mathrm{c}$ & $43.00 \mathrm{~b}$ & $4.30 \mathrm{~b}$ & $1.82 \mathrm{c}$ & 2.362 \\
\hline$(\mathrm{RP}+\mathrm{RK})+$ bio & $3.50 \mathrm{a}$ & $127 \mathrm{~b}$ & $45.04 \mathrm{a}$ & $5.72 \mathrm{a}$ & $2.33 \mathrm{a}$ & 2.454 \\
\hline $\operatorname{LSD}_{0.05}$ & 0.23 & 1.35 & 1.35 & 0.17 & 0.12 & \\
\hline
\end{tabular}

SP-super phosphate; KS-potassium sulfate; RP- rock phosphate; RK- feldspar; G/Sgrains : straw yield ratio. Different letters within a column indicate a significant difference at $\mathrm{P} \leq 0.05, \mathrm{n}=3$. 


\section{Conclusion}

It can be concluded that, the combined application of mixture strains with rocks rock phosphate and feldspar to alkaline soil increased the efficiency of $\mathrm{P}$ minerals in soil. In addition, the utilization of biofertilizers with the direct application of rocks (RP $+\mathrm{RK})$ in soil increased NPK uptake and the yield parameters of wheat plants grown in alkaline soil. This suggests their potential use as fertilizers in alkaline soil.

\section{Reference}

Abd El-Ghany, B.F., Arafa, R.A., El-Rahmany, T.A. and El-Shazly, M.M. (2010) Effect of some soil microorganism on soil properties and wheat production under north Sinai conditions. J. Appl. Sci. Res., 4(5): 559-579.

Allen, S.F., Grimshaw, H.F. and Rowl, A. B. (1984) Chemical analysis. In: "Methods in Plant Ecology”. Eds. Molore, P. D. and S. B. Chapman Blackwell, Oxford pp. 185344.

Bishni, U. R. and Hughers, I. L. (1979) Agronomic performance and protein content of content of fall-planted tritica, wheat and rye. Agron. J., 71: 359-360.

Brady, N. C. (1990) "The Nature and Properties of Soils", Macmillan, New York, USA, pp. 351-380.

Cakamka, R. Kantar, F. and Algur, O. F. (1999) Sugar beet and barley and yield in relation to Bacillus polymyxa and Bacillus megaterium var. phosphaticum inoculation. J. Plant Nutr. Soil Sci., 162: 437-442.

Chapman, H. D. and Pratt, P. F. (1961) "Methods of Analysis of Soils", plant and water. Cal. Univ. 150-200.

Chen, J. (2006) The combined use of chemical and fertilizers and /or biofertilizers for crop growth soil fertility. International Workshop on Sustained Management of the soil-rhizosphere System for Efficient Crop Production and Fertilizer use 16-20.

De Sousa, L. P. and De Silva, M. J. (2012) Differential growth of Jatropha curcas L. by different strain of entophytic Bacillus sp. International J. Agricultural Science and soil Science., 2 (8): 306-311.

El- Haddad M. E., Ishac Y.Z. and Mustafa M. (1993) The role of biofertilizers in reducing agriculture costs, decreasing environmental pollution and raising crop yield. Arab.Unvi. J. Agric. Sci. Ain Shams Univ. 1 (1): 147-195.

El-Shanshoury, A. R. (1995) Interaction of Aazotobacter chroococcum, Azospirilium brasilense and Streptomyces mutabilis in relation to their effect on wheat. J. Agron. \& Crop Sci., 175: 119-127.

Frie, E., Payer , K. and Schuttr, E. (1964) Determination of phosphorus by ascorbic acid method. Schw. Land Wirtsh. Forschung, Heft., 3:318-328.

Egypt. J. Bot., 55, No. 2 (2015) 
Gerke, I. (1992) Phosphate, aluminum and iron in the soil solution of three different soils in relation to varying concentrations of citric acid, Z. Pflanzenernahr. Bodenk., 155:17-22.

Gouzou, L., Burti, G., Philippy, R., Bartoli, F. and Heulin, T. (1993) Effect of inoculation with Bacillus polymyxa on soil aggregation in wheat rhizosphere (preliminary examination), Geoderma, 56: 479-491.

Han, H. S., Supanjani and Lee, K.D. (2006) Effect of co-inoculation with phosphate and potassium solubilizing bacteria on mineral uptake and growth of pepper and cucumber. Plant Soil Environ., 52:130-136.

Holl, F. B., Chanway, C. P., Turkington, R. and Radley, R. (1988) Response of crested wheat-grass (Agropyron cristatum L.) perennial ryegrass (Lolium perenne L.) to inoculation with Bacillus polymyxa. Soil Biol. Biochem., 20:19-24.

Kabesh, M. O., El-kramany, M. F., Sary, G. A., El-Naggar, H.M. and Gehana. S.H. (2009) Effect of sowing methods and some bio-organic fertilization treatments on yield and yield components of wheat. Res. J. Agric. \& boil. Sci., 5:97-102.

Lee, J.Y. and Song, S. H. (2007) Evaluation of ground water quality in coastal areas, implications for sustainable agriculture. Enivron. Geol., 52: 1231-1242.

Mehrvarz, S. and Chaich, M. R. (2008) Effect of phosphate solubilizing microorganisms and phosphorus chemical fertilizer on forage and grain quality of barely (Hordeum vulgare L.). American-Eurasian J. Agric. \& Environ. Sci., 3(6):855-860.

Mengel, K. and Kirkby, E. A. (1987) “Principles of Plant Nutrition”, International Potash Institus, Bern, Switzerland.

Omar, M.N.A. and Seddik, W.M. (2007) Effect of biofertilizers containing $\mathrm{N}_{2}$-fixer, $\mathrm{P}$ and $\mathrm{K}$ solubilizes on wheat and maize yield at Ismailia site. $12^{\text {th }}$ Conference of microbiology, Cairo, Egypt. 352-363.

Park, M., Singvilay, O., Seok, Y., Chung, J., Ahn, K. and SA, T. (2003) Effect of phosphate solubilizing fungi on uptake and growth Tobacco in rock phosphate applied soil Korean. J. Soil Sci. Fertil., 36:233-238.

Premsekhar, M. and Rajashree, V. (2009) Influence of bio-fertilizers on the growth characters, yield attributes, yield and quality of tomato of American-Eurasian. $J$. Sustainable Agric., 3:68-70.

Rajan, S. S., Walkinson, J. H. and Sinclair, A. G. (1996) Phosphate rock for direct application to soil. Advances in Agron., 57: 77-159.

Rigby, D. and Caceres, D. (2001) Organic farming and sustainability of agricultural system. Agric. Syst., 68: 21-40.

Rodriguez, H. and Fraga, R. (1999) Phosphate solubilizing bacteria and their role in plant growth promoting. Biotech. Advances, 17(4): 319- 339. 
Rodriguez, H. , Gonzalez, T., Goir, I. and Bashan, Y. (2004) Gluconic acid production and solubilization by the plant growth-promoting bacterium Azospirillum spp., Naturwissenschaften, 91: 552-555.

Rosen, S. (1993) "Agriculture Policy Reform: Issues and Implications for Africa. Foreign Agriculture Economic", Report No 250 Washington, D.C.: United states Department of Agriculture.

Sheng, X. F., He, L. Y. and Huang, W. Y. (2002) The conditions of releasing potassium by a silicate-dissolving bacteria strain NBT. Agr. Sci. China, 1: 662-666.

Subba Rao, N.S. (1984) "Biofertilizers in Agriculture". $3^{\text {th }}$ ed. Oxford and IBH Publishing Co., New Delhi, India, pp: 1-3, 83, 132 \& 153-165.

Snedecor, G. W. and Cochran, W. G. (1982) "Statistical methods", $7^{\text {th }}$ ed. The Iowa State Univ. Press, Iowa, USA.

Supanjani, Han, H. S., Jung, J. S. and Lee, K.D. (2006) Rock phosphate-potassium and rock-solubilising bacteria as alternative, sustainable fertilisers. Agron. Sustain. Dev., 26:233-240.

Vessey, K.J. (2003) Plant growth promoting rhizobacteria as biofertilizers. Plant soil., 25:557-586

Tiwari, V. N., Lehri, L.K. and Pathak, A. N.(1989) Effect of inoculation crops with phosphor-microbes. Exp. Agro., 25:47-50.

Yasari, E. M., Esmaeil, S. M. and Mahsa, R. A. (2009) Enhancement of growth and nutrients uptake of rapeseed (Brassica napus L.) by applying mineral nutrients and biofertilizers. Pakistain J. Biol. Sci., 12 (2): 127-133.

Yazdani, M., Bahmanyar, M. A., Pirdashti, H. and Esmail, M. A. (2009) Effect of phosphate solubilization microorganism (PSM) and plant growth promoting rhizobacteria (PGPR) on yield and yield components of corn (Zea mays L.). World Academy of Sci. Eng. \& Technol., 49: 90-92.

Zapata, F. and Roy, R. N. (2004) "Use of Phosphate Rock for Sustainable Agriculture". FAO and IAEA Rome, Italy.

Zayed, G. (2005) Bio-production of compost with low $\mathrm{pH}$ and high soluble phosphorus from sugar cane bagasse enriched with rock phosphate. World J. Microb and Biotech., 21: 747-752.

(Received 18/12/204 accepted 19/2/2015) 


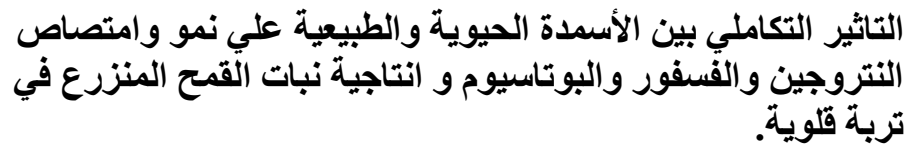

لميس دسوقي شعبان ',كمال محمد السيد خليل' ، ريهام السعيد محمود

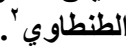
قسم النباتــ كلية العلوم - جامعة الزقازيق و معهد بحوث الأراضي والمياه

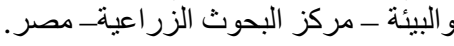

اجريت هذه الدراسة لتقيم التأثير التكاملي بين سلالات بكتيريا الباسيلس "باسيلس

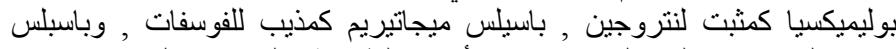

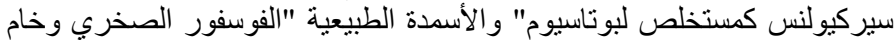

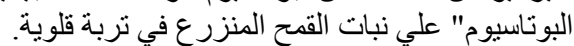

لقد سجلت النتائج ان تسميد نبات القمح بخليط من الأسمدة الحيوية

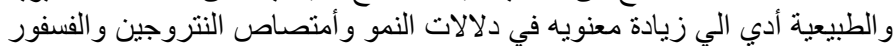

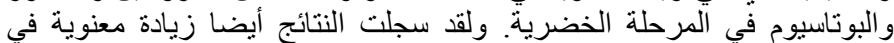

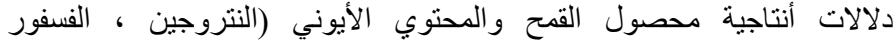

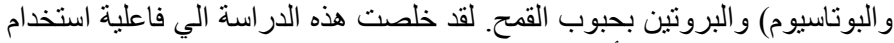

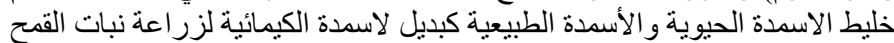
في التربة القلوية. 